\title{
U źródeł myśli Trzeciego Teologa i Filozofa Prawosławia
}

\author{
Michał Dżega \\ Polska \\ dzegmichal@gmail.com \\ Michał Dżega, At the source of thought of the Third Theologian and Philosopher of Orthodoxy, Elpis, 17 2015: 155-158.
}

Polska patrologia jak dotąd nieźle prezentuje się na arenie międzynarodowej, choć są takie jej zakątki, które pozostają dalej niezbadane. Dla prawosławnego czytelnika niezwykle problematycznym jest zaniedbanie badania oraz wydawania źródeł prawosławnej myśli teologicznej, obejmującej okres po 5. Soborze Powszechnym (553 r.). Takowej serii jak dotąd brak, co sygnalizuję. Ukazują się raz na jakiś czas, dodajmy rozproszone w różnych seriach pozycje, które jednak nie łatwo jest zebrać w jedną sensowną całość. O ile prace Świętych Ojców czterech pierwszych stuleci są przedmiotem ożywionych badań w Polsce (np. śww. Augustyn, Ambroży, Leon Wielki, Grzegorz Wielki), jak też ukazują się ich coraz to nowsze wydania krytyczne. To w przypadku tych Św. Ojców Wschodu tworzących od VI wieku zaczynamy mieć poważne luki. Recenzowana książka z pewnością stara się na ile jest to możliwe, chociażby w sposób doraźny tą lukę zapewnić. Jako duży plus tej pracy trzeba podkreślić to, że studium to jest stricte pracą z zakresu teologii i filozofii. Jest to tym bardziej znaczące, gdyż po dzień dzisiejszy ukazują się nagminnie w Polsce rozprawy o teologii bez cienia teologii w tle, o tej pracy tego powiedzieć nie można.

Postać św. Maksyma Wyznawcy († 662) otwiera ów orszak zaniedbanych Św. Ojców Wschodu - tą prawdziwą i namacalną lukę w polskiej patrologii, na próżno bowiem szukać po polsku całościowych edycji dzieł takich Św. Ojców jak: Teodora Studyty, Focjusza Wielkiego, Symeona Nowy Teolog, Nicetasa Stethatosa, Grzegorza z Synaju, Grzegorza Palamasa, Marka Eugenikosa. Nie tak dawno zostały wydane przekłady dzieł św. Jana Klimaka oraz św. Jana Moschosa, co należy przyjąć z radością (zob. Drabina raju, przekł. W. Polanowski, Kęty 2011; Słowo do Pasterza. Łąka duchowa, przekł. J. Brylowski, Warszawa 2012.).

Osoba św. Maksyma Wyznawcy zajmuje w teologii Wschodu bezsprzecznie ważne miejsce, starczy powiedzieć, że św. Maksyma określano mianem «Trzeciego Teo-

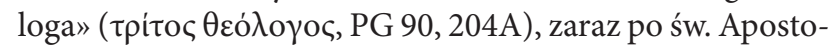
le i Ewangeliście Janie i św. Grzegorzu z Nazjanzu, a przed św. Symeonem ihumenem monasteru Studios. Życie św. Maksyma było niezwykle ciężkie, hartowała go bezlitośnie. Za swoją wierność Ortodoksji stracił nie tylko język i prawą rękę, został wrogiem samego cesarza, ekskomunikowany przez trzech ówczesnych wschodnich patriarchów.
W końcu zapytany przez heretyckiego patriarchę Piotra do jakiej należy Cerkwi: Bizantyńskiej, Rzymskiej, Antiocheńskiej, Aleksandryjskiej, Jerozolimskiej?, św. Maksym stanowczo odrzekł: Bóg wszechrzeczy objawił Powszechna Cerkwia prawidłowe i zbawcze wyznanie wiary w Niego, nazywajac błogosławionego Piotra za to, iż ów wyznat Go (Mt 16, 18). Naprzód, chcę poznać warunek, przez który dokonało się zjednoczenie wszystkich Cerkwi, i jeśli uczyniono to wtaściwie, nie będę się od tego oddalat (PG, 91, $132 \mathrm{~A}$. Por. $P G, 90,93$ D.). Był zdeterminowany do tego stopnia, że wyraził swoją gotowość na śmierć w imię zachowania Ortodoksji: „wole jednak umrzeć niż cierpieć wyrzuty sumienia $z$ powodu choćby najmniejszego odstępstwa od swej wiary w Boga" ( $z \dot{Z}$ ywotu).

Ŝw. Maksym swoimi dziełami obejmuje wszystkie sfery chrześcijańskiego życia i filozofii. Cerkiew Prawosławna wychwala Go jako nie tyle «księcia Filozofów» (jak czynią to katoliccy względem Tomasza z Akwinu), bowiem Cerkwi Wschodniej obce jest dzielenie Św. Ojców na tych większych i mniejszych (por. z katolicką koncepcją Doktorów i Doktorek Kościoła). W przypadku św. Maksyma Cerkiew pokazuje Go jako Nauczyciela Cerkwi i Filozofa (nie zapomniawszy o Jego Męczeństwie), nie ze względu na Jego nieprzeciętą wiedzę oraz przenikliwy rozum w tym doczesnym i śmiertelnym świecie. Nie należy odczytywać tego jako pochwałę samej Jego wiedzy czy erudycji, przeciwnie jest to pokazanie prawdziwej filozofii, której św. Maksym jawi się mistrzem. Cerkiew osobę św. Maksyma przeciwstawia tym wybitnym starożytnym filozofom, którzy choć uznawali filozofię za naukę o rzeczach boskich i ludzkich, to jednak nie zdołali osiągnąć prawdziwej Mądrości. Cerkiew Prawosławna zaś widzi w św. Maksymie prawdziwego Filozofa, tj. tego który pokochał Chrystusa - Prawdziwą Hipostazę Mądrości Bożej, Boga Logosa. Co ważniejsze to poznanie jest ściśle powiązane z praktyczną realizacją jego głównego postulatu, jakim jest jednoczesne z Jego poznaniem, upodobnianie się Bogu. Pisze o tym św. Jan z Damaszku: Filozofia jest upodabnianiem się Bogu. Upodobniamy się do Boga przez mądrość, to znaczy przez prawdziwe poznanie dobra, $i$ wedle sprawiedliwości, która jest sprawiedliwym podziałem i niezważaniem na osoby $w$ sadzie, oraz wedle świętości, która wyższa jest od sprawiedliwości, czyli przez bycie dobrym i czynienie dobra tym, którzy nam wyrządzaja 
niesprawiedliwość (Św. Jan Damasceński, Dialektyka albo rozdziały filozoficzne, przekł. i oprac. A. Zhyrkova, Kraków 2011, s. 37.). Jest to gwarantem osiagnięcia prawdziwego poznania rzeczy boskich i ludzkich. Równie ważne, że dla Cerkwi Prawosławnej owe poznanie Prawdziwej Mądrości jest możliwe i dostępne dla wszystkich (co jest obce dla gnostyków oraz Barlaama z Kalambrii), wymaga ono bowiem jednego - miłości, która jest drogą do Mądrości Bożej, miłości w Chrystusie i dla Chrystusa. Poznanie rzeczy boskich i ludzkich nie należy rozumieć jako poznawanie Boga, ale jak pisze Apostoł Paweł - jako bycie poznanym przez Boga: Gdyby ktoś mniemał, że coś „wie”, to jeszcze nie wie, jak wiedzieć należy. Jeżeli zaś ktoś mituje Boga, ten zo-

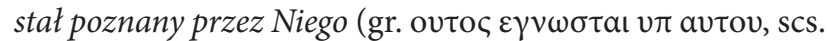
познан бысть от Него) (1 Kor. 8: 2-3). Św. Maksym wierzył, że Boga można osiągnąć na drodze ponadrozumowej oraz ponadzmysłowej kontemplacji. Wyznał też w swych Centuriach gnostyckich: Wiedze bowiem zdobywamy tylko

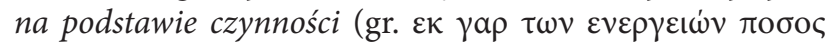

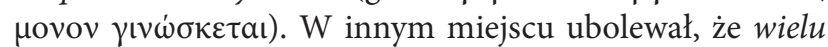
$z$ nas jest rozprawiajacych, mało zaś praktykujących (Księga o miłości, IV, 85.).

Damasceńczyk widzi w filozofii coś jeszcze: Filozofia następnie jest umiłowaniem madrości. Prawdziwa zaś mądrość jest Bogiem, tak więc mitość do Boga sama jest prawdziwa filozofia. (Dialektyka..., s. 38.). Dlatego Damasceńczyk sprawiedliwe $\mathrm{w}$ swym kanonie wychwala św. Maksyma słowami: $\Sigma o \varphi i ́ \alpha \varsigma \tau \tilde{\eta} \varsigma \dot{\alpha} \mu \varepsilon i v \omega \tau \tilde{\omega} \tilde{\varepsilon} \rho \omega \tau l, \tau o \tilde{v}$ X Dla Damasceńczyka św. Maksym jest napełniony poprzez Ducha Świętego prawdziwą Mądrością Bożą. Doskonalenie się w miłości, przestrzeganie przykazań (w tym dogmatów) i nabywanie cnót - tym jest filozofia z perspektywy prawdziwego prawosławnego chrześcijaństwa.

Dlatego Cerkiew wychwala i daje swym dzieciom za wzór św. Maksyma, ażeby wezwać je do bycia prawdziwymi filozofami Boga. Takimi bowiem byli pierwsi naśladowcy Chrystusa - Święci Męczennicy. Mało tego w jednym z liturgicznych tekstów wychwalających Życiodajny Krzyż czytamy: Радуйся Кресте, имже познася единым мгновением разбойник богословеи, взываяй: помяни мя, Господи, во Царствии Твоем. (Триодион, сиесть Трипеснеи, М., 1897. Л. 166 об. В среду 2-я седмицы. Утреня. Песнь 8. Ин трипеснец.) Droga do osiągnięcia prawdziwej filozofii jest na tyle dostępna, że mogą i osiągają ją rybacy, faryzeusze, nierządnice oraz dobry łotr. Damasceńczyk w swej Dialektyce poucza: Nie ma nic cenniejszego od poznania: jeżeli bowiem poznanie jest świattem duszy rozumnej, to brak poznania jest ciemnością. Jak bowiem brakiem światta jest ciemność, tak brakiem poznania jest ciemność rozumu. Nierozumnym właściwa jest niewiedza, rozumnym zaś - poznanie. Ten więc, kto nie posiada poznania, będąc $z$ natury zdolny do poznania i zdobywania wiedzy, chociaz wedlug natury jest rozumny, to $z$ powodu zaniedbania i lekkomyślności duszy jest gorszy od stworzeń nierozumnych. (...) nie od siebie zaś dusza posiada poznanie i wiedzę, lecz potrzebuje pouczajacego - przystapmy więc do nauczyciela niefatszywego: do prawdy. Chrystus zaś jest uosobiona Ma- drościa i Prawda, w Nim sq ukryte wszystkie skarby wiedzy (por. Kol 2, 3) oraz jest On Mądrościa i Moca Boga Ojca (por. 1 Kor 1, 24) (Dialektyka..., s. 35-36.).

Prawdziwe poznanie jest dla św. Maksyma niczym innym jak samą wiarą: „Wiara jest bowiem prawdziwym poznaniem, opierającym się na zasadach, których nie trzeba udowadniać ( $\alpha v \alpha \pi o ́ \delta \varepsilon ı \kappa \tau o \varsigma ~ \alpha \rho \chi \alpha ́ \varsigma)$, ponieważ stanowia substancję rzeczy wykraczajacych ponad ducha i rozum" (Księdze Oświeconych, I, 9). Prawidłowe rozumienie dogmatów Cerkwi opiera się na pojmowaniu ich rozumem cerkiewnym (o czym św. Maksym nie raz pisał), i tej interpretacji i rozumieniu powinien być wierny każdy pragnący być prawdziwym prawosławnym chrześcijaninem.

Postać św. Maksyma pozostaje przedmiotem ciągłych badań współczesnych teologów, głębia myśli św. Maksyma wydaje się być nieskończoną. Jego Twórczość jest na tyle bogata, że zwyczajnie nie zasługuje na umiejscawianie jej w drugim szeregu. Ostatnia wydana bibliografia badań nad twórczością św. Maksyma zawiera 3133 pozycji (sic!) (zob. Кнежевић М. Максим Исповједник (580-662): Библиографија. Београд: Институт за теолошка истраживања ПБФ, 2012. (Библиографија српске теологије. Кн. 6); oraz rec. А. Г. Дунаев w: Богословские труды. 2013. Bып. 45. C. 488-490.), co pokazuje tylko jak bardzo wiele poświęca się Jej dalej miejsca. Choć od razu trzeba ostudzić tych którzy sądzą, że ogarnięto już wszystko co napisał św. Maksym. Nic mylącego, być może nie rozumiemy więcej niż nam się może wydawać. Słusznie autorka zauważyła to, że postawą udanych badań jest poszukiwanie oryginalnych dzieł oraz dokumentów związanych z żywotami danego autora (s. 23). Należy stwierdzić, iż wywiązuje się Ona z tego niezwykle sumiennie, dogłębnie analizując różne poruszane przezeń kwestie studium.

Gdyby nie liczyć antologii dzieł św. Maksyma (zob. Maksym Wyznawca, Antologia życia wewnętrznego, Dialog o życiu wewnętrznym, Księga miłości, Księga oświeconych, Wykład Modlitwy Pańskiej, Listy o miłości, z języka greckiego tłumaczył A. Warkotsz, druk Pallotinum, Poznań 1980.) oraz studium M. Jankowiaka (patrz. tegoż, Żywoty Maksymusa Wyznawcy, [w:] Chrześcijaństwo u schyłku starożytności. Studia źródłoznawcze, t. V, red. T. Derda, E. Wipszycka, Kraków 2004, s. 153-196.), któremu polski czytelnik zawdzięcza zapoznanie się z syryjskim Żywotem św. Maksyma wydanym przed laty przez S. Brocka (zob. An Early Syriac Life of Maximus the Confessor, Analecta Bollandiana 91 (1973), pp. 299-346.); to nie ostało by się praktycznie nic godnego polecenia polskiemu czytelnikowi (sic!). I tu trzeba dodać, że tłumaczenie A. Warkotsz było pierwszym tak całościowym tłumaczeniem dzieł Maksymowych na język nowożytny (tym milej, że był to język polski) w skali światowej(!).

Autorka recenzowanej pracy korzysta z ponadczasowej pracy S. L. Epifanowicza (1886-1918) o św. Maksymie (Епибанович С. Л. Преподобный Максим Исповедник и византийское богословие. Киев. 1915); jednak autorka nie wie (sic!) o tym, że odnaleziono i wydano w druku część drugiego tomu tego dzieła. Okazało się bowiem, że S. L. Epifanowicz poświęcił tej tematyce nie tylko swoją 
kursową pracą, ale i poszerzył ją w swej pracy magisterskiej, która osiągnęła ilość ponad 2400 stron (!). I chociaż była zatwierdzona do obrony, to jednak geniusz uważał ją za niepełną i odłożył jej obronę. Obroniona w Kijowskiej Duchownej Akademii w 1917 roku (Материаль $\kappa$ изучению жизни и творений преподобного Максима Исповедника. Киев. 1917), niestety nie została w całości wydana. W pewien sposób zadośćuczyniono temu dopiero w 2013 roku w Petersburgu staraniem wydawnictwa Olega Abyszko (zob. С. Л. Епифанович. Преподобный Максим Исповедник. Его жизнь и творения. В 2 т. СПб., 2013.). Tym bardziej ubolewam, iż autorka z przyczyn nieznanych mi, nie sięgnęła do tego wydawnictwa, drugi tom bowiem jest wnikliwą analizą myśli teologicznej i filozoficznej św. Maksyma, podczas gdy pierwszy skupia się jedynie nad Jego życiem).

Autorka nie zna również głównego oponenta S. L. Epifanowicza prof. M. D. Muretowa (1850-1917) (zob. częściami w: Жизнь, дела и мученичество преподобного отиза нашего и исповедника Максима, пер. изд. и прим. М. Д. Муретова, Богословский Вестник, 1913, Т. 1, № 1, С. 1-16; 1913, Т. 2, № 6, С. 65-96; 1913, Т. 3, № 7/8, C. 97-128; 1913, Т. 3, № 9, С. 129-144; 1913, Т. 3, № 10, C. $145-220$; 1913 , T. 3 , № 11, C. $161-176$; 1914 , T. 1 , № 1, C. 193-208; 1914, T. 1, № 2, C. 209-224; 1914, T. 1, № 4, C. $225-240 ; 1914$, T. 2, № 6, C. $257-272 ; 1915$, T. 1 , № 1, C. 273-288; 1915, T. 2, № 5, С. 289-297. Ukazało się też oddzielne wydanie, zob. Творения святого отияа нашего Максима Исповедника. Ч. 1. Житие Преподобного Максима и службы ему / Пер., изд. и прим. проф. М. Д. Муретова. Сергиев Посад, 1915.).

Autorce należało by jeszcze zapoznać się z pracą prof. A. Brilliantowa, zob. О месте кончины и погребения св. Максима Исповедника, СПб. 1918 (jest to odbitka z: Христианский Восток. Петроград. 6, 1918. С. 1-62, przedrukowana ostatnio w: Бриллиантов А. Император Константин Великий и Миланский эдикт 313. О месте кончины и погребения св. Максима Исповедника, СПб. 2006.).

$\mathrm{Na}$ koniec zaś jeszcze sygnalizuje autorce istnienie szkicu drugiego oponenta prof. Epifanowicza gruzińskiego prof. protojereja K. Kekelidze (1879-1962), zob. Сведения грузинских источников о препод. Максиме Исповеднике // Труды Киевской Духовной Академии, 1912. С. 1-77.

Warto powiedzieć w tym miejscu, że w dorewolucyjnej patrystyce rosyjskiej św. Maksymowi nie poświęcono, aż tak dużo miejsca, również przekładało się to na przekłady Jego dzieł (zob. Г. И. Беневича, Прп. Максим Исповедник в России // Прп. Максим Исповедник, Богословско-полемические сочинения (Ориscula Theologica et Polemica) / Пер. с древнегреч. Д. А. Черноглазова и А. М. Шуфрина; науч. ред., предисл. и коммент. Г. И. Беневича, СПб. 2014, С. 679-720.).

Najbardziej jednak zadziwia brak znajomości współczesnych rosyjskich wydawców dzieł św. Maksyma. Współczesna rosyjska patrologia nadrabia zaległości wobec św. Maksyma. Jednak na próżno szukać w recenzowanej rozprawie takich cennych tytułów z serii «Smaragdos Philo- calias», jak: Диспут с Пирром: преподобный Максим Исповедник и христологические споры VII столетия, отв. ред. Д. А. Поспелов, М. 2004 z cennym wstępem samego redaktora, zob. s. 15-144; oraz przekładem listów Maksymowych pióra E. Naczinkina (Максим Исповедник, Письма. / Пер. с древнегреч. Е. Начинкин, СПб., Изд-во СПбГУ, 2007.; Прп. Максим Исповедник и его соратники: документы из ссылки / Сост. Г. И. Беневич; отв. ред. Д. А. Поспелов. М. 2012; a także: Прп. Максим Исповедник, Богословско-полемические сочинения (Оризсиа Theologica et Polemica) / Пер. с древнегреч. Д. А. Черноглазова и А. М. Шуфрина; науч. ред., предисл. и коммент. Г. И. Беневича, СПб.: Издательство РХГА, 2014.

Również szkice do kolejnych wydań dzieł św. Maksyma pióra prekursora współczesnych tłumaczeń Maksymowych w Rosji prof. A. I. Sidorow są autorce nie znane (zob. Максим Исповедник, преп. Творения / Пер., вступ. статья, комм. Сидорова А. И. М. 1993, Т. 1-2, w tomie 1, s. 7-74 oraz komentarze tegoż do obu tomów.), w końcu ostatnie tłumaczenie Capita theologia (Loci communes) autorstwa P. K. Dobrocwietowa, które wywołało ostrą falę dyskusji w środowisku naukowym (zob. «Пчела» или «Богословские главы» преп. Максима Исповедника / Перевод, вступит. ст., примечания, послесловие П. К. Доброцветова. M. 2013.). Brak też ważnej pozycji W. Lourié о historii filozofii bizantyńskiej (В. М. Лурье, История византийской философии. Формативньй период, СПб. 2006.), która stała się pozycją obowiązkową wśród podręczników z filozofii bizantyńskiej. Warto było by zapoznać się z wybitną rosyjską antologią tekstów patrystycznych: Антология восточно-христианской богословской мысли (ортодоксия и гетеродоксия), М.-СПб. Изд-во: Никея-РХГА, 2009, в 2-х тт..

Warte odnotowanie jest wydanie dzieł Maksymowych pióra D. A. Czernogłazowa z cennymi komentarzami G. I. Benewicza (zob. Прп. Максим Исповедник, Вопросы и недоумения / Пер. Д. А. Черноглазова, науч. ред., предисловие и комментарии Г. И. Беневича, М. 2010.), jest to jeden $\mathrm{z}$ wiodących we współczesnej rosyjskiej patrystyce znawców św. Maksyma (podaje dwa przykładowe szkice tegoż: Иоанн Филопон и Максим Исповедник: от христианизации философии к христианской философии, „Религиоведение”. № 1, 2011. С. 107-113; О применении философии к триадологии и космологии в экзегезе прп. Максима Исповедника, „Вестник ЛГУ им. Пушкина”, № 1, Т. 2. Философия. 2011. С. 45-54.). Wykaz nieznanych autorce rosyjskich wydań Maksymowych zakończę na owocami polemiki przeciwko orygenizmowi oraz monoenergizmowi: Максим Исповедник, Полемика с оригенизмом и моноэнергизмом, СПб., Изд-во СПбГУ, 2007 (tamże, na s. 13-153, interesujący szkic Дело Максима pióra G. I. Benewicza wespół z A. M. Szufrinym).

Również pewnym uszczerbek wnosi do tej skądinąd całkiem porządnej rozprawy, marginalne - powiedzieć przypisowe potraktowanie recepcji dziedzictwa Maksymowego w liturgice (hymnografii) i ikonografii (przyp. 116 ze s. 59-60.). Mogę tylko zasygnalizować szkice gruzińskiego biskupa Stefana (Kalaidzhishvili): Современный 
взгляд на вопрос о месте переселения кончины и погребения св. Максима Исповедника в Грузии // Труды XV Ежегодной богословской конферениии ПСТГУ, М. 2005. C. 232-245; tegoż, K вопросу о переложении мощей преподобного Максима Исповедника // Труды XVIII Ежегодной богословской конференции ПСТГУ, Т. I, М. 2008. С. 359-363. Tam zob. interesujące propozycje odnośnie losów relikwii św. Maksyma oraz specyfiki jego liturgicznej pamięci. Odnośnie tej ostatniej konieczne jest zapoznanie się $\mathrm{z}$ ostatnimi częściami pracy prof. Muretowa na łamach $\mathrm{Bo}-$ gosłowskiego Wiestnika, gdzie dokonał on analizy tekstów liturgicznych oraz Synaksarów dedykowanych św. Maksymowi (zob. Жизнь, дела и мученичество преподобного отиза нашего и исповедника Максима, пер. изд. и прим. М. Д. Муретова, Богословский Вестник, 1914, Т. 1, № 4, С. 234-240; 1914, Т. 2, № 6, С. 257-272; 1915, Т. 1, № 1, С. 273-288; 1915, T. 2, № 5, C. 289-297.).

Równie godne polecenia autorce są trzy staroruskie służby do św. Maksyma, opublikowane przez M. Murjanowa (zob. Мурьянов М. Ф. Гимнограбия Киевской Руси, M. 2003. 222-249, 250-252, 439-446.).

Przechodząc do układu samej pracy, podzielona jest ona na dwie części, obejmujące kolejno dziedzictwo oraz twórczość św. Maksyma na tle jego żywota. Pierwsza cześć to analiza recepcji dorobku św. Maksyma w tradycji średniowiecznej, z uwzględnieniem obu ówczesnych kręgów chrześcijańskich: łacińskiego i bizantyńskiego. Autorki nie stroni też od wypadów w czasy te bliższe naszym, jednak należało by te rozważenia przenieść do oddzielnego rozdziału (np. Dziedzictwo św. Maksyma w XX wieku). Nie można bowiem ani zapominać, ani się oszukiwać - dopiero XX wiek przyniósł poważne zainteresowanie osobą św. Maksyma, starczy tylko spojrzeć na ilość XX-wiecznych wydań jego dzieł. Przekracza ona kilkukrotnie wszystkie wydania z wcześniejszych stuleci. Niewątpliwie zasługują one na wydzielenie ich $\mathrm{z}$ obecnej lokalizacji w recenzowanej rozprawie. Druga część to przedstawienie tytułowej kwestii rozwoju poglądów na tle jego losów. Autorka dla próby odpowiedzi na to stawiane przezeń pytania o źródła myśli św. Maksyma próbuje wyrazić za pomocą tematycznego kluczu, umożliwiającego czytelnikowi ogarnąć liczne jego wędrówki po rozległych obszarach greckiego Wscho- du i łacińskiego Zachodu w poszukiwaniu prawdziwej filozofii.

Brakuje $\mathrm{w}$ recenzowanej pracy $\mathrm{z}$ pewnością pokrótce przedstawionego życia św. Maksyma, nie można bowiem ani artykułu M. Jankowiaka, ani wstępu do wydania A. Warkotsza, uznać za wystarczająco wyczerpujące. To też polskiemu czytelnikowi przyjdzie się jeszcze poczekać na porządną rodzimą pracę poświęconą św. Maksymowi.

Recenzowana praca po mimo swoich pewnych mankamentów zasługuje na godną polecenia, wszystkim tym którzy chcą poznać postać św. Maksyma Wyznawcy. Prawosławny czytelnik rzadko ma bowiem możliwość zetknięcia się w języku polski z pracami poświęconymi twórczości Ojców Prawosławnego Wschodu. Niech nie zraża również czytelnika ciężkość zagadnień związanych z twórczością św. Maksyma, jest to cecha charakterystyczna tego wielkiego Ojca Cerkwi Wschodniej. To ma też swe odbicie w języku używanym przezeń, na którym nie jeden wybitny tłumacz łamał swe pióro. Być może dopiero przyszłość pozwoli nam na lepsze zrozumienie twórczości św. Maksyma, o ile zechcemy tylko poświęcać jej więcej swej uwagi. Na marginesie dodam, że przykładem może posłużyć wydany w tym roku: Oxford Handbook of Maximus the Confessor, eds. P. Allen \& B. Neil, Oxford University Press: Oxford 2015, zawierający 29. artykułów podzielonych na 4. części, poświęconych osobie, twórczości i dorobku św. Maksymowi. Redaktorzy tomu zaproponowali własną chronologię życia św. Maksyma (zob. tamże, s. 14-15.). Oxford Handbook of Maximus the Confessor moim zdaniem pretenduje do miana najlepszej z dotychczasowych studiów nad osobą św. Maksyma. Niestety jak dotąd pozostaje niezauważony wśród polskich badaczy (sic!).

Recenzowana rozprawa na pewno zmusza do dalszych studiów nad spuścizną Maksymowych, stąd łaskawa moja prośba do autorki pracy, kontynuować swe badania o św. Maksymie z oddaniem i determinacją równą tej kijowskiego prof. Epifanowicza, zechciawszy również uwzględnić moje skromne uwagi.

B. Kosmulska, Historyczne i doktrynalne uwarunkowania rozwoju myśli Maksyma Wyznawcy, Warszawa 2004. $220 \mathrm{~s}$. 
ISSN 1508-7719

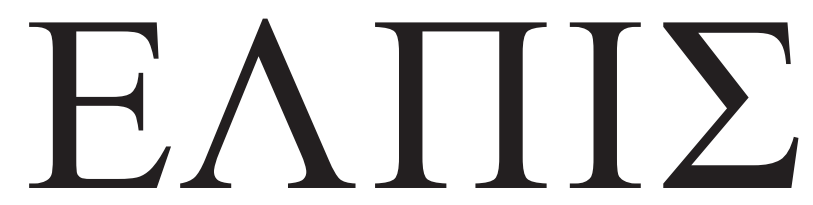

CZASOPISMO TEOLOGICZNE KATEDRY TEOLOGII PRAWOSŁAWNEJ UNIWERSYTETU W BIAŁYMSTOKU

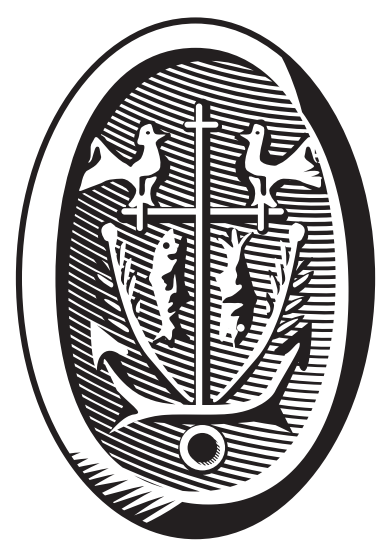

ADRES REDAKCJI

15-097 Białystok, ul. M. Skłodowskiej-Curie 14 tel. 85 745-77-80, e-mail: redakcja@elpis.edu.pl www.elpis.uwb.edu.pl 